\title{
Conceptualización de la ciudad y su territorio. Tendencia geométrica del imaginario urbano
}

\author{
Conceptualization of the city and its territory. \\ Geometric trend of the urban imaginary
}

\section{Resumen}

Autores:

Lola Goytia-Goyenechea goytia@us.es

Nieves Martínez-Roldán nmr@us.es

Departamento de Urbanística y Ordenación del Territorio. Universidad de Sevilla

España
E hombre, ante su entorno, a través de la percepción y sobre sus recursos intelectuales ha procesado siempre los estímulos recibidos. En base a ello ha conceptualizado: una idea de la ciudad en la que habita, construida por él; una percepción del territorio en el que vive, que ha transformado a lo largo del tiempo; y una noción del mundo en el que está inmerso, que ha logrado interpretar. Esta conceptualización, generada progresivamente desde los orígenes del hombre, nos ha dejado imágenes de su representación que nos permiten aproximarnos con rigor a su conocimiento a través del análisis de sus contenidos y de los contextos en que se han generado. De ello se desprende que lo que el hombre es capaz de conceptualizar desde lo visual significa siempre un determinado entendimiento espacial, siendo en lo urbano frecuentemente de tendencia geométrica, en el cual es fundamentalmente la referencia abstracta de una realidad concreta que tiene su reflejo correspondiente en la representación.

Palabras clave: conceptualización del espacio, imaginario urbano, cartografía

\section{Abstract:}

Man, in his environment, through perception and his intellectual resources, has always processed the stimuli received. Based on it, he has conceptualized: an idea of the city in which he inhabits, built by him; a perception of the territory in which he lives, which he has transformed over time; and a notion of the world in which he is immersed, which he has managed to interpret. This conceptualization progressively generated from the origins of man has left us images of his representation that allow us to rigorously approach his knowledge, through the analysis of its contents and the contexts in which they have been generated. From this it follows that what man is able to conceptualize from the visual always means a certain spatial understanding, being in the urban frequently of geometric tendency, and this is fundamentally the abstract reference of a concrete reality that has its corresponding reflection in the representation.

Keywords: conceptualization of the space, imaginary of the urban, mapping 


\section{Introducción}

Conocer el Universo que le rodea ha sido siempre una constante en el hombre desde que adquirió esa condición, y ello por la curiosidad intelectual inherente al ser humano y también por múltiples motivos utilitarios, que van desde atender a la propia subsistencia, a considerar aspectos defensivos, comerciales, políticos o de control. En todo caso el hombre ha concebido intelectualmente su propio ámbito espacial, urbano y territorial como paso previo o requisito necesario para ejercer su acción.

Suele aceptarse que la representación de esa concepción intelectual previa del espacio es innata. Cualquier individuo de cualquier pueblo, por primitivo que sea, dibuja sobre el suelo el camino hacia el lugar preguntado, o señala gráficamente a sus compañeros de caza la dirección y distancia de la presa. Está así confeccionando un mapa, y ese y no otro es el origen de la cartografía. Esta innata actividad de representar gráficamente la concepción intelectual del espacio se manifiesta de innumerables formas: se representa al mundo y el cosmos porque el filósofo precisa explicárselo a sus discípulos; se representa una parcela de terreno para disponer el campamento militar; se describe una provincia para conocerla o gobernarla; se dibujan las costas y sus accidentes para evitar naufragar. Sin duda, en su inicio la cartografía tuvo una finalidad práctica, pero también sirvió para ayudar al hombre en la necesidad de reducir lo infinito, lo complejo, lo inabarcable, a una dimensión que posibilite su comprensión. Con la cartografía, el mundo, o más bien la idea del mundo, puede estar en una hoja de papel y esto resulta extraordinario.

Al contrario que el mundo, y aun el territorio, la ciudad es sobre todo un hecho histórico, un sistema de relaciones entre humanos y entorno territorial que, una vez constituido, evoluciona a lo largo del tiempo, transmitiendo a sus ciudadanos una cierta conciencia de pertenecer y tener como suyo un patrimonio comunitario identificador. En este contexto la representación de la ciudad es una de las constantes más permanentes de la historia del hombre. La necesidad de captar y transmitir el valor de la ciudad implica inevitablemente su previa conceptualización a través de un proceso complejo de abstracción, pues no hay que olvidar que la ciudad no es una mera suma de estilos de arquitectura, y tampoco que su representación de ninguna forma es inmediata ni intuitiva, sino compleja y supeditada a un previo proceso de abstracción intelectual que genera en cada individuo su propio imaginario urbano.

En este sentido no cabe duda que el análisis de la cartografía constituye un método válido, e incluso fundamental, para acceder a la concepción intelectual del ámbito espacial representado, bien del observado o incluso imaginado $y$, a través de ella, entender su significado. Sobre este fundamento, yaunque tal vez no se haya investigado suficientemente sobre ello, especialmente desde la disciplina urbanística, las nuevas tecnologías irrumpen ofreciéndonos nuevas herramientas para recolectar el imaginario colectivo que ya se nos manifiesta virtualizado frente al imaginario tradicional gráficamente representado.

\section{La percepción del entorno como fundamento de toda conceptualización}

La capacidad de percepción constituye el fundamento que posibilita nuestra relación con el medio exterior en general, y en particular con el entorno formalizado. La información se recibe por los sentidos, pero, y esto es sobradamente conocido, solo constituye una referencia primaria sobre la que la mente humana desarrolla un complejo proceso perceptivo, de forma que el hombre culturizado, de hecho, no recibe sensaciones puramente objetivas como referencia de información.

A partir de toda información o estímulo, el hombre visualiza un mundo que incluye su propio conocimiento o idea de la realidad.

Los humanos percibimos los hechos a través de la mirada y los interpretamos a partir de nuestro conocimiento o prejuicio previo. En nuestra mente, resulta de ello la idea de realidad, que es el hecho objetivo tal como lo percibimos y entendemos cada uno de nosotros. Es decir que la realidad es la percepción subjetiva de la objetividad fenomenológica (Folch y Bru, 2017, p.40).

Este hecho, objeto de profundos debates e investigaciones, alcanza incluso al campo de la filosofía a través del pensamiento relativista, que diferencia entre lo que la realidad es y lo que la realidad significa en la capacidad cognoscitiva humana. En este orden de cosas lo cultural deviene así como esencial para la percepción de una realidad exterior que no existe de forma objetiva, sino únicamente como construcción intelectual propia, y es esa fundamentación cultural la que construye realidades espaciales diferenciadas a partir de percepciones del entorno personalizadas. El imaginario urbano así formalizado "parece cubrir la ciudad material, los lugares, con innumerables velos, parciales, móviles, fragmentados, superpuestos, que dejan ver ciertos fenómenos y ocultan otros, dependiendo del sujeto y del tiempo" (Lindón, 2007a, p.12).

\subsection{Componente psicológica de la percepción}

Son sobradamente conocidos los trabajos de Rudolf Arnheim, desarrollados a comienzos del pasado siglo dentro de la denominada Escuela de Berlín. Estudios en relación a la psicología de la percepción de la forma, o Gestalt Psicologie, en donde se analiza el proceso de 
construcción intelectual del hecho perceptivo. La Gestalt planteó cómo la forma emerge al articular sensaciones y experiencias en función de unas ciertas leyes sobre las que fundamenta esta articulación. Elementos que se ofrecen en el campo visual, sujetos a ciertas relaciones se perciben traducidos en formas que destacan sobre e fondo del panorama visual.

En este sentido la percepción no es una traducción litera de un conjunto de estímulos, sino el resultado de una cierta organización de estos estímulos a través de claves selectivas precisas, como pueden ser: el principio de semejanza, el principio del cierre, la ley de la pregnancia, el principio de proximidad, el principio de dirección común, el principio de continuidad, la ley de simetría, el principio de simplicidad, el principio de relación entre figura y fondo, y el principio de la experiencia, entre otras. En este sentido se entiende la Gestalt como "una teoría encargada de orientar la tendencia de la conciencia hacia la racionalidad" (Leonardo, 2004, p.93)

La trascendencia de la Gestalt, que interesa destacar en este caso, en relación con el mundo de lo visual, "reside en el hecho de situar lo perceptivo dentro de un marco influido por la cultura de cada tiempo, la experiencia y el aprendizaje, que condiciona nuestra eficacia en la aplicación de las leyes cristalizadoras de la forma" (Arias, 2003, p.95). La percepción resulta ser así el resultado de un proceso biunívoco entre el observador y el medio observado, creando el observador una imagen que le es propia pero en la que existen puntos de conexión que sirven de puente entre la hipotética representación y la sugerente realidad (Uribe, 2005).

De acuerdo con esto, la conceptualización de lo percibido es siempre, en lo urbano y en lo territorial, una respuesta referida a un cierto espacio físico, y que frente a la ceguera ante las imperfecciones formales, expresada por la Gestalt como la ley de la plenitud de las formas de Wertheimer, formula la tendencia de la percepción hacia la simetría, la simplicidad y la fundamentación geométrica, o al menos regular.

\section{Diferencia entre la con- ceptualización de lo urbano, lo territorial y el cosmos}

La percepción tiene componentes de distinta naturaleza según se refiera a ámbitos naturales, a otros formalmente construidos por la acción del hombre, o a otros inabarcables directamente. Es decir, según se refiera a lo territorial, a lo urbano, o al cosmos respectivamente.

Lo que caracteriza a las sociedades primitivas es e contraste que se erige entre el territorio que habitan y el espacio desconocido que rodea al mismo. El primero constituye su mundo, mientras que lo envolvente ya no es un cosmos sino otro mundo, un espacio misterioso, anárquico y habitado por foráneos. Esta oposición entre un territorio vivido y estructurado, y por tanto cosmizado, y el espacio incomprendido que se prolonga más allá de sus límites, nos permite afirmar que de un lado se tiene un cosmos y del otro un caos.
El entendimiento del cosmos siempre ha resultado esencial en la historia, y ello porque establece los vínculos entre el hombre y la realidad trascendente, lo sobrenatural y la religión, impregnando así todas las acciones del ser humano. Al entender el cosmos, el hombre se entiende, asimismo, al sentido trascendente de su vida, su significación en el orden superior, y también accede al mundo y a los valores de lo sobrenatural, inicialmente de lo mítico y después de lo religioso.

La conceptualización del cosmos se ha llevado a cabo, en principio y supuestamente, sobre una realidad existente y al margen de la acción humana, ya que el hombre está inmerso en él, sin capacidad alguna de incidir sobre esa realidad que penosamente intentará comprender. Los elementos que se le ofrecen: los astros, los días y las noches, los meteoros, el clima, los mares y continentes, son componentes que, al margen de su capacidad de intervención, le irán aportando información sobre la que conceptualizar su idea de esta realidad esencial para su vida, y aun para comprender el sentido de la misma desde la que afrontará su representación, que plasmará por primera vez en un modelo de la Asiria mesopotámica sobre el s. IX a.C.

Es un hecho que hasta el momento en que, con el descubrimiento de América, se completara parcialmente la visión del mundo, germinaron distintas cosmovisiones, a partir de diferentes conceptualizaciones, derivadas de diversas referencias culturales (Figura 1).

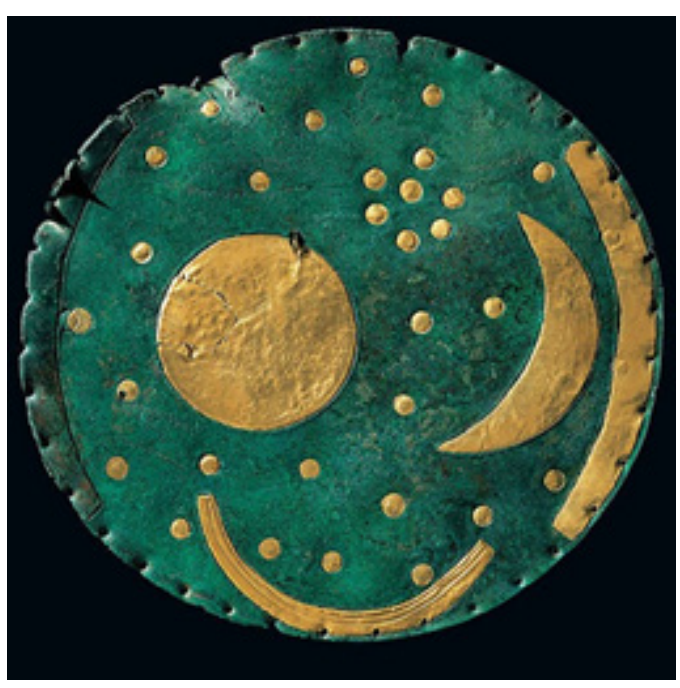

Figura 1: Disco celeste de Nebra [1600 a.C.]. Oficina de Gestión del Patrimonio y la Arqueología de SajoniaAnhalt, Alemania. Museo Estatal de Prehistoria de Halle. Descubierto en Sajonia en 1999, presenta un esbozo de cosmovisión ya en la Edad de Bronce. Se trata de un disco de bronce con piezas de oro que representan el sol, la luna, el arco del horizonte y treinta y dos estrellas entre las que se distingue la constelación de las Pléyades. Este enigmático disco es sensiblemente contemporáneo al plano de la ciudad de Nippur.

Fuente: UNESCO. Recuperada el 24/01/2019 de:

http://www.unesco.org/new/fileadmin/MULTIMEDIA/ $\mathrm{HQ} / \mathrm{Cl} / \mathrm{Cl} /$ images/mow/germany nebra sky disc recto. jpg 
Respecto al territorio, antes incluso de las civilizaciones primitivas, el hombre había advertido que el mundo, cuyo sentido iba progresivamente desvelando, era variado y diverso en sus territorios, por lo que estos tenían un valor diferenciador que resultaba esencial. También muy pronto apreció que, mediante su actividad, ese territorio era moldeado de una determinada forma, a través de su cultivo, de las acciones sobre él y de otros hechos, de forma que las culturas fueron reconociendo su territorio conformado como algo propio, diferenciado, y dotado de valor y significación. En definitiva, como algo que está en profunda e íntima relación con él mismo. Así, el territorio, conformado por la cultura del hombre, fue progresivamente adquiriendo la categoría de valor, fijándose como identidad y, lo que será aún más importante, incluso como centro del mundo y fundamento de todo su entendimiento.

La constante relación espacio-sociedad que enmarca a los individuos implica que en la medida que van forjando su propia identidad, tomando como referencia su contexto territorial, van asumiendo mecanismos para la asignación de valores y significados, apegos y pertenencias, narrativas y categorizaciones, especialmente a los lugares, espacios vividos y de vida, lo que les facilita construir de estos una representación y un imaginario territorial (Avendaño, 2017, p.58).

Estos hechos han sido una evidencia constante en todas las culturas y civilizaciones, desde la Babilonia mesopotámica a los polder holandeses ganados al mar, estableciéndose profundas e íntimas relaciones entre el hombre y el territorio en el que desarrolla su vida y al que modula progresivamente, construyendo así un patrimonio que se enraíza en su propia identidad y que adquiere para él, aun inconscientemente, un valor por completo esencial (Figura 2).

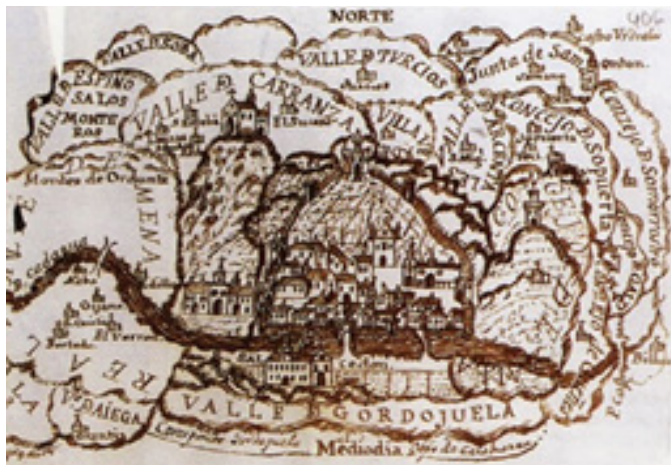

Figura 2: Vista de Balmaseda (España). Anónimo 1794 Núcleo castellano fundado el año 1199 en Vizcaya, con traza regular, durante el reinado de Alfonso VIII de Castilla, el Noble [1159-1214]. El desconocido autor tiene muy claros los conceptos que pretende expresar, y nos muestra la ciudad regular con sus principales elementos urbanos: la muralla, el puente, el castillo, la parroquia y los monasterios, perfectamente integrada en un territorio transformado por la acción del hombre. Fuente: Biblioteca digital de ciencia y cultura vasca. Recuperada el 24/01/2019 de: http://hedatuz.euskomedia.org/3891/1/01810208es.pdf

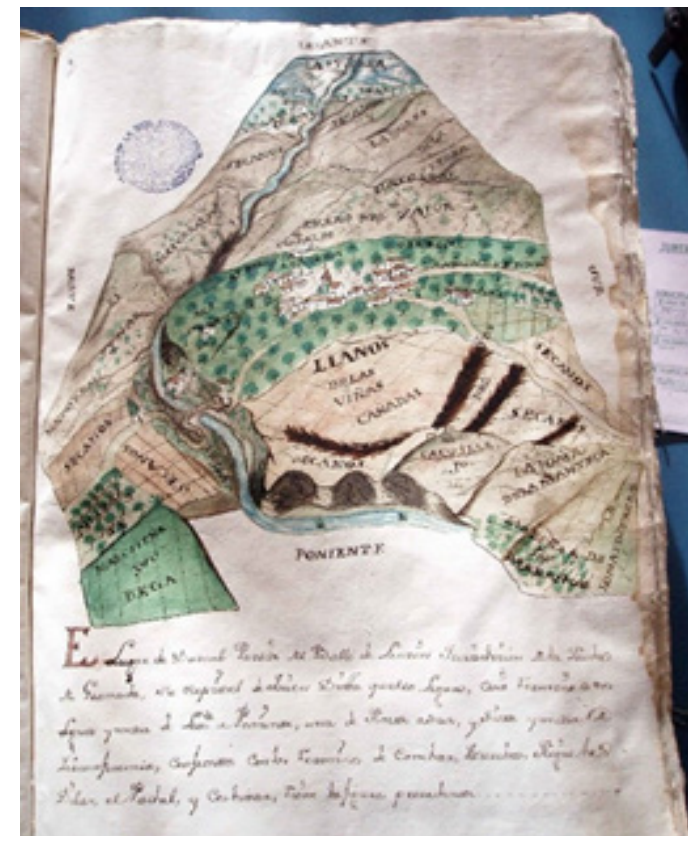

Figura 3: VCatastro del Marqués de la Ensenada. Valle de Lecrín, Dúrcal (Granada, España), 1752

Plano resultado de los planes reformistas del Marqués de la Ensenada, reforma fiscal que generó un importante patrimonio documental.

Fuente: Ayuntamiento de Dúrcal. Recuperado de: http://www.adurcal.com/enlaces/mancomunidad/guia/ caminos/1750.htm

Registrar las distintas percepciones sobre soportes variados permitía al hombre apoderarse de su entorno y conocerlo a través de identificar ciertos rasgos en el territorio. Este hecho, que al principio tuvo un origen funcional, con el tiempo será el reflejo de una expresión ideológica de intereses, alterándose de forma consciente la realidad representada (Sáinz y González, 2015, p.23) (Figura 3).

De forma similar, aunque no idéntica, se produce el proceso respecto a lo urbano, por ser ésta una realidad totalmente construida por el ser humano, a diferencia del mundo que le ha sido dado, y del territorio al que solo modula con su acción. Es en el espacio urbano donde el hombre ha situado fundamentalmente el centro de su referencia vital y aún existencial, de forma que la progresiva formación del concepto de lo urbano y su desarrollo marchará a lo largo del tiempo de forma paralela a la propia construcción de la ciudad, y arraigará en el hombre aún con más fuerza que respecto al territorio por tratarse de algo construido, aunque no fue hasta el s. XIX cuando, desde John Ruskin a Camillo Sitte, se toma conciencia de los valores que posee la ciudad, independientemente de lo puramente formal.

Trátese de las iniciales representaciones babilónicas de la ciudad, de los balbuceos perspécticos de la imagen urbana del español prerrenacentista en su búsqueda de completar el conocimiento del orbe, de los dibujos en las décadas de los 70 y 80 del siglo pasado de los hermanos García Fernández, de las ciudades del pintor Antonio López o las fotografías de Scott Stulberg, entre 
otros, se puede afirmar que la visión conceptualizada de lo urbano está en el fundamento y constituye la clave de todo entendimiento de la ciudad, creándose progresivamente nuevas lecturas de lo urbano, que "nos permiten reconstruir estadíos pretéritos y avanzar hipótesis sobre paisajes perdidos" (Chías, 2018, p.118), e incluso anticipar un futuro incierto (Figura 4).

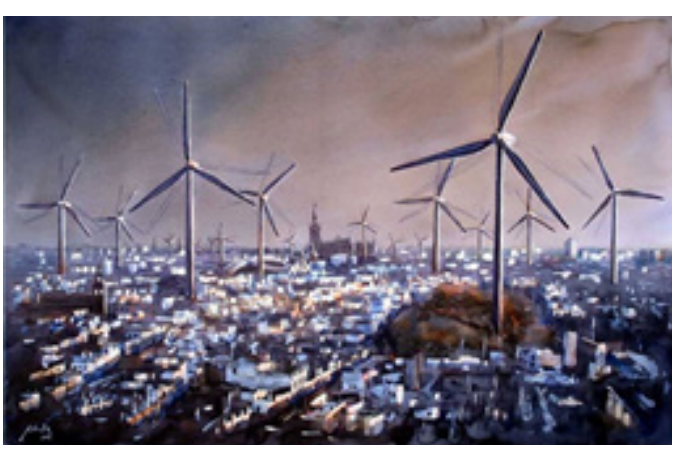

Figura 4: Sevilla, paisajes futuristas, ciudades sostenibles de Juan Manuel Santaella, 2010

Fuente: Santaella, J.M. (2019). Juan Manuel Santaella, artista plástico. Recuperada el 14/03/2019 de: https://juanmanuelsantaella.com/portfolio/pinturacontemporanea/

Se deduce, por tanto, que las conceptualizaciones del cosmos, del territorio y de lo urbano se sustentan sobre fundamentaciones específicas y distintas, y es probablemente esto lo que ha originado que sean muy escasas las representaciones en las que se ha pretendido sintetizar estas tres categorías, como ocurre en la excepcional representación atribuida al miniaturista francés Simón Marmión [1425-1489] (Figura 5).

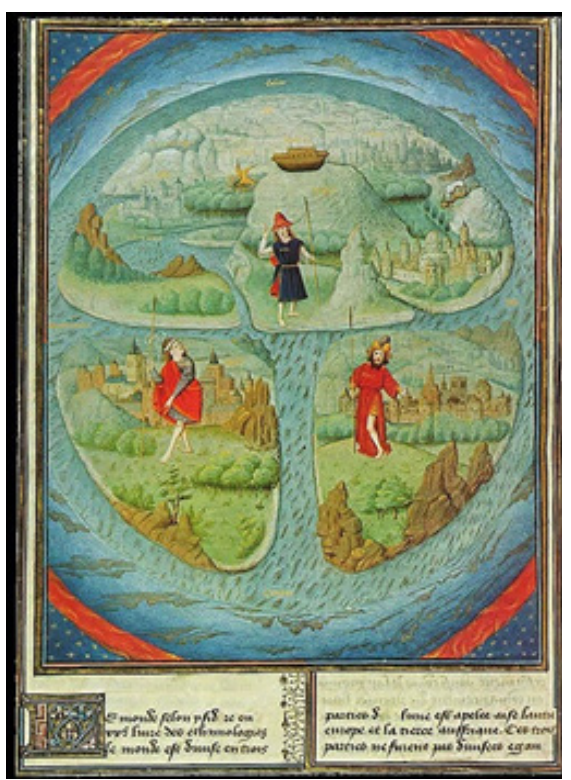

Figura 5: Miniatura de Simón Marmión, 1450.

Mapamundi realizado para el códice ilustrado de las Grandes Crónicas de Francia, a mediados del s.XV, en donde se representa a los hijos de Noé habitando los distintos continentes en los cuales se aprecia la representación de ciudades.

Fuente: Bibliothéque Royale Albert I, Ms 9231, fol.281v.
Mucho más frecuentes son las representaciones en las que se recoge directamente lo urbano en el territorio, como ocurre ya desde las tablillas de Nippur, y tres milenios más tarde se aprecia en el "Teatrum Orbis terrarum" de 1587. En todo caso el análisis de esa relación urbano-territorial ha resultado siempre relevante, hasta constituirse en la actualidad en una clave esencial de entendimiento del espacio y en elemento imprescindible para la planificación urbanística.

La ciudad está compuesta por múltiples representaciones, imágenes, historias e imaginarios urbanos, que intervienen en los procesos de urbanización. Con base a esta idea se considera relevante indagar los imaginarios urbanos en los discursos, a través de los cuales se proyecta una ciudad. En este sentido, los planes de políticas públicas se presentan como un recurso valioso a partir de lo cual se puede rastrear la creencia de lo que la ciudad es en el presente, la reconstrucción imaginaria de lo que fue y las esperanzas que abraza con miras al futuro (Vera, 2013, p.153).

De lo expuesto se desprende que la construcción de la forma que el hombre es capaz de conceptualizar desde lo visual significa siempre un determinado entendimiento espacial. Esa conceptualización del espacio es fundamentalmente la referencia abstracta de una realidad siempre concreta, que tiene su reflejo correspondiente en la representación, lectura que puede alterarse, como se muestra en los siguientes apartados, atendiendo a nuevas experiencias vividas durante un viaje, a la relación espacio - tiempo condicionada por los medios de transporte y las nuevas tecnologías, o incluso en función del valor simbólico que tenga un determinado lugar para una colectividad, entre otras causas.

\section{El viaje en la percepción del territorio y de lo urbano}

El entendimiento del cosmos, en principio, no demandó de la movilidad como clave primaria, al sustentarse su percepción sobre la observación de aspectos como la alternancia día/noche, los astros, los meteoros, que a su vez eran percibidos e interpretados sobre la referencia cultural. No obstante, el mundo, como objeto a descubrir necesita del movimiento como pieza clave para su entendimiento, que será inevitablemente progresivo y dilatado en el tiempo. Conceptualmente esto remite a la ruta y al itinerario como hecho perceptivo, es decir, como realidad que en sí misma significa un valor que compromete al observador en ámbitos existenciales más allá de lo previamente conocido, y así la significación de la ruta para el viajero se inscribe en una dimensión más amplia, como pueden ser los valores que se fundamentan en lo descubierto $y$, sobre ello, en la relectura y reelaboración de lo conocido.

Viajar a lo ignoto, adquirir el conocimiento e investigar lo lejano para contarlo, normalmente de forma exagerada, está en la base de la naturaleza humana y de su afán de conocimiento, y el plano o el mapa alcanzan su sentido y naturaleza como necesidad de mediación para la divulgación de lo conocido. Descubierto algo, o 
pretendiendo haberlo conocido, es cuando se está en condiciones de reducirlo a lo entendible y a lo abarcable.

Sin embargo, no cabe pensar que la mera percepción y el conocimiento de lo novedoso por el viajero conlleva automáticamente su aceptación, y mucho menos que, aunque esta se produzca, pueda imitarse en la sociedad que recibe la novedad aportada por e viajero, y ello porque habría también que reproducir las condiciones que le dieron su origen, cuestión esta normalmente imposible de conseguir. Es por esto por lo que los modelos, aunque frecuentemente admirados, no pueden ser reproducidos y, si esto llega a hacerse, la traspolación siempre produce alteraciones en el mismo. En todo caso, el hombre ha conseguido mediante el viaje, independientemente de las múltiples finalidades que le han motivado a emprenderlo, un vasto conocimiento de territorio y de lo urbano. Ejemplo de ello es la fundación de la villa cristiana de Nagasaki por la Compañía de Jesús, entre 1570 y 1578 (Figura 6).

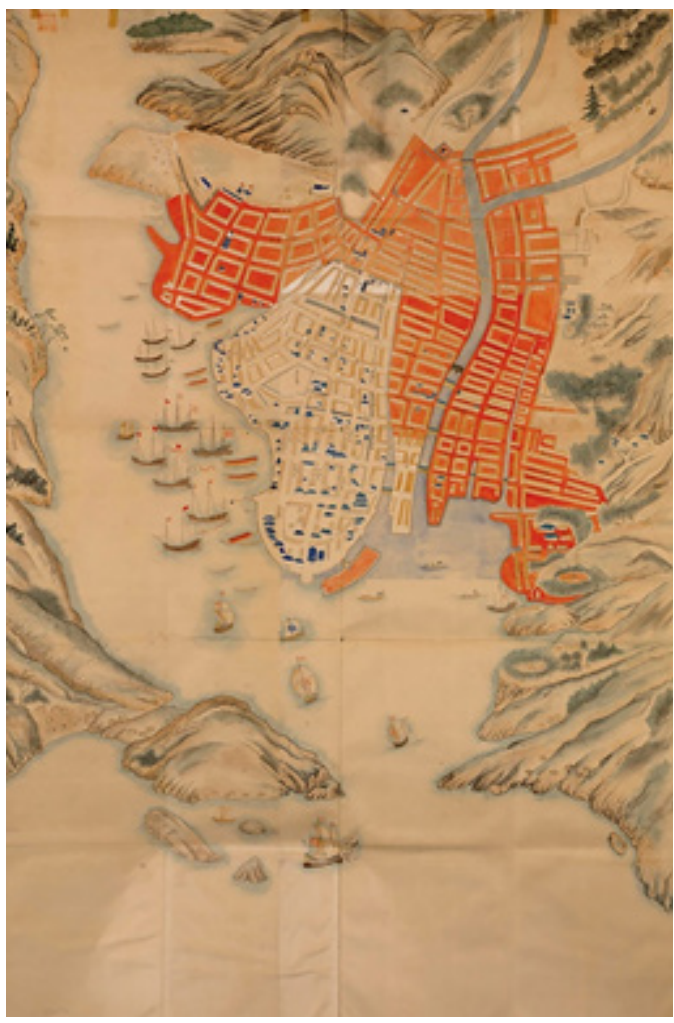

Figura 6: Nagasaki, 1637. Autor desconocido.

Nagasaki supone una praxis desarrollada por los jesuitas conocida como la "accommodatio". Reconociendo el nivel de la cultura, las costumbres, y la sociedad fuertemente jerarquizada de Japón, la orden propugna la inculturación, la hibridación entre dos culturas como modo de intervención urbana. Como consecuencia de ello en su trama se pueden diferenciar formas urbanas del imaginario cristiano occidental que conviven con otras del imaginario geomántico japonés.

Fuente: Nagasaki Museum of History and Culture. Recuperada el 01/07/2019 de:

http://www.nmhc.jp/museumlnet/prh/colArtAndHis SubGet.do?command=image \&number $=148525$
Por lo tanto el imaginario urbano no solo se nutre de la conceptualización realizada de la imagen percibida, sino de recuerdos y experiencias de esos viajes que permiten nuevas reinterpretaciones. Al respecto destacar lo que Hiernaux-Nicolás (2002) define como imaginario turístico:

...el imaginario turístico sería, aquella porción de imaginario social referido al hecho turístico, es decir las numerosas manifestaciones del proceso societario de viajar. En una porción de nuestra mente, conservamos esas apreciaciones e imágenes, de tal suerte que, en cualquier momento, y a través de hechos cotidianos no forzosamente ligados al imaginario, podemos reformular y reacomodar éste último... El imaginario es entonces algo vivo, un proceso inacabado, sujeto a revisiones, ajustes, cambios, y nuevas interpretaciones aun de hechos viejos. Un ejemplo de ello es la información que recibimos regularmente acerca de un país: la prensa, los eventos cotidianos relatados por la televisión o la radio, no forzosamente se relacionan con la imagen turística que nos hacemos de ese sitio, pero contribuyen a deconstruir/reconstruir esta imagen (pp. 8-9).

\section{La relación espacio-tiempo en la percepción de lo urbano.}

Así como la percepción del cosmos se ha sustentado sobre el paso del tiempo, la alternancia día-noche y la movilidad de los cuerpos celestes, la percepción del espacio ha estado siempre vinculada a la movilidad del observador. Toda percepción de lo urbano se basa en un encadenamiento de secuencias espaciales necesario para la posterior conceptualización de la ciudad. "La ciudad es el resultado de este encadenamiento secuencial y, en última instancia, el resultado visual de tal encadenamiento" (Arias, 2003, p.102). Como consecuencia de ello, la memoria, la secuencia de imágenes, el espacio, el tiempo y el modo de desplazamiento tienen una gran significación en el proceso de percepción de lo urbano.

La irrupción del automóvil, ha provocado que los nuevos modos de percepción ya no estén basados en la secuencialidad lineal, donde la dimensión espacial y temporal están estrechamente vinculadas. Los largos desplazamientos necesarios en la vida diaria provocan una separación cada vez más acentuada entre ambas dimensiones, dando lugar a una ciudad fragmentada en la que el espacio entre origen y destino queda difuminado. La ciudad que en sus inicios tuvo una imagen coherente pierde su sentido de unidad rodeada de una amplia periferia que obliga a mayores recorridos. A mayor velocidad, los tiempos de desplazamiento son menores y la percepción del espacio se desdibuja percibiendo solo fragmentos de dicha realidad. Estas nuevas características dinámicas provocan percepciones fragmentadas, de carácter múltiple, y de forma simultánea, provocando la yuxtaposición de imágenes que alteran la vivencia de la realidad espacio temporal, al igual que ocurre en algunas secuencias cinematográficas (Terán, 2002). 
Esta pérdida de la visión de conjunto de nuestro entorno, como consecuencia del dominio de los medios de transporte, unida a la utilización masiva de las nuevas tecnologías ha provocado que el espacio público pierda su tradicional función de espacio de relación, y por tanto deje de tener un papel predominante en el imaginario urbano colectivo. En este sentido y como contrapartida es necesario que las políticas urbanísticas tiendan en la actualidad a potenciar espacios para el peatón que nos permitan percibir de forma más directa nuestro entorno (Figura 7).

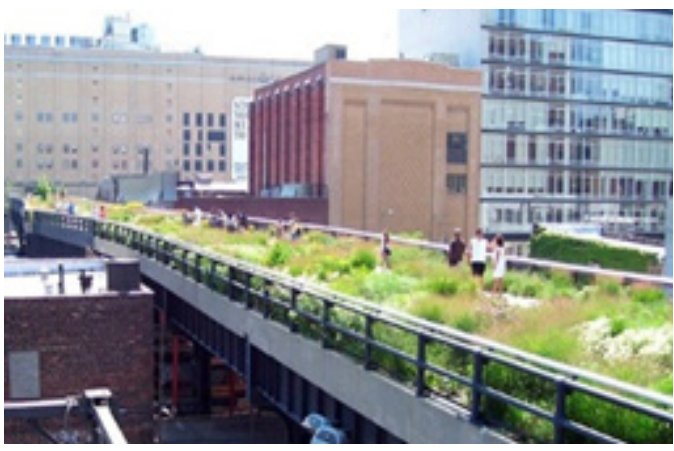

Figura 7: High Line. Manhattan (Nueva York)

Parque construido a $10 \mathrm{~m}$ sobre el nivel de la calle, sobre un antiguo viaducto ferroviario que conecta tres barrios de la isla de Manhattan

Fuente: Arquitectura y empresa. Recuperada el 02/07/2019 de:

https://www.arquitecturayempresa.es/noticia/high-lineuna-antigua-infraestructura-ferroviaria-transformadaen-ejemplo-de-futuro

En relación a esta realidad, y debido a que la mencionada fragmentación afecta principalmente a la percepción del espacio público, Domenico di Siena (2010) investiga sobre la necesidad de romper la rígida estructura de nudos conectados en red de la ciudad fragmentada, que ha provocado distorsiones en el imaginario urbano a través de la conexión de la dimensión presencial y virtual para la mejora del espacio público, conformando lo que llama como "espacio híbrido", que modifica la lógica de espacio urbano tradicional, y en donde la tecnología digital establece sinergias con el espacio físico. Ejemplo de ello es la propuesta de la Plaza de las Libertades en Sevilla, espacio de $30.000 \mathrm{~m} 2$ concebido como un nuevo nodo urbano donde experimentar con los usos sociales de las nuevas tecnologías.

En este escenario queda patente cómo los sistemas de comunicaciones y las nuevas tecnologías inciden modificando nuestra percepción sobre el entorno y distorsionando el imaginario urbano.

\section{El "lugar" en la conceptualización de lo urbano}

Toda referencia urbana es, en definitiva, un lugar, e incluso en espacios anónimos y despersonalizados se puede señalar éste o aquél lugar. Los lugares son así espacios en algo singulares que, como tales, son reconocidos socialmente por los ciudadanos, pudiendo también diferenciarse los no lugares, que a veces se significan incluso con denominación precisa que expresa la razón o el fundamento de su singularidad. Tal como expresa Augé (2000): "Si un lugar puede definirse como espacio de identidad, relacional e histórico, un espacio que no puede definirse ni como espacio de identidad ni como relacional, ni como histórico, definirá un no lugar" (p.44)

En general, el carácter de lugar lo otorgan los propios ciudadanos en función de razones que no siempre resultan explícitas, pero que tienen una profunda relación con su selectiva valoración de lo urbano y también con la forma de utilizar la ciudad, porque para que un lugar efectivamente lo sea es preciso que tenga diversas cualidades: debe ser suficiente y auténtico en un sentido pragmático y también debe permitir que el individuo actúe en él de la forma deseada.

Se reconoce que los espacios urbanos, siendo físicos, no tienen el mismo valor para todos sus habitantes. Entonces lo que adquiere sentido no es el espacio material en si mismo, sino más bien, el espacio simbólico que se crea entre los que habitan en ellos, conformándose una relación dialéctica entre la dimensión física y la dimensión subjetiva asociada a esta (Zenteno, 2018, p.105).

Habida cuenta de esta dimensión subjetiva, Zenteno (2018) plantea la reflexión sobre la necesidad de establecer nuevas metodologías que permitan discernir esta dimensión de la ciudad, tan compleja debido a su carácter individual para su aplicación en actividades de intervención urbana. Ejemplo de ello son los mapas perceptivos, en donde "el espacio urbano es representado por los habitantes de la ciudad en una dimensión propiamente emotiva y subjetiva, expresando el modo en que el barrio es vivido." (Zenteno, 2018, p.108) (Figura 8).

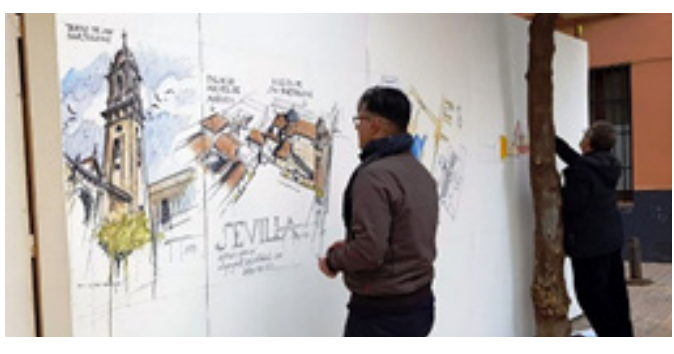

Figura 8: Urban sketchers en la Torre de San Bartolomé (Sevilla)

El movimiento social urban sketchers, a través de sus dibujos en la calle, ayudan a crear conciencia social sobre la importancia del paisaje urbano y su patrimonio. Fuente: Parroquia de San Bartolomé y San Esteban. Recuperada el 30/06/2019 de:

https://sanbartolomeysanesteban.org/dando-vida-colorla-base-del-andamio-nuestra-torre-galeria-fotografica/

En otro contexto, son también lugares significados aquellos espacios que contienen o están presididos por algún elemento emblemático o significativo para la ciudad. La iglesia, la plaza, el edificio público... referencian siempre espacios que solo por esta razón se significan y son el soporte justificativo de los lugares más expresivos (Figura 9). 


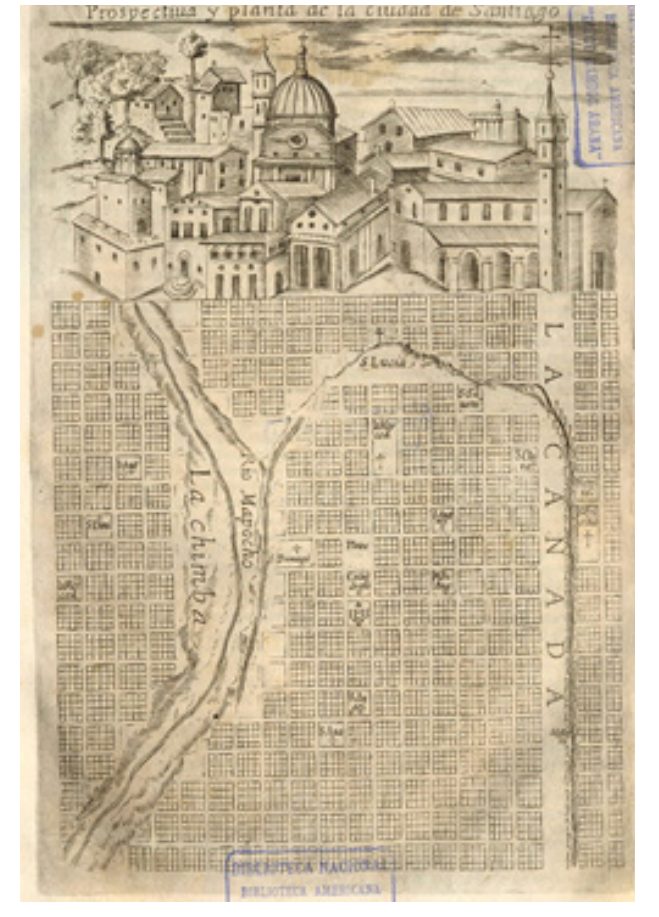

Figura 9: Santiago de Chile de Alonso de Ovalle, 1646 Plano en el que se significan los lugares más emblemáticos y se traza en retícula la trama urbana exagerando su geometría de acuerdo con el imaginario urbano del jesuita Alonso de Ovalle.

Fuente: Biblioteca Americana Diego Barrios Arana.

En todo caso la persistencia de la significación de los lugares de la ciudad proporciona una de las más expresivas lecturas de lo urbano, y es una referencia valiosa de la memoria histórica que permanece vigente como soporte de la vida ciudadana.

\section{La representación de la imagen conceptualizada de lo urbano}

Al contrario que el mundo y el territorio, la ciudad es sobre todo un hecho histórico. En las estructuras físicas de la ciudad está impresa, como en un palimpsesto, su historia y evolución como proceso de crecimiento y transformación, siendo el plano de la ciudad el documento más expresivo y explícito de la misma. Además de ello, toda ciudad transmite a sus ciudadanos una cierta conciencia de pertenecer y tener como suyo un patrimonio comunitario identificador que da sentido a la realidad. Este sentido trasciende lo urbano y lo cualifica no ya por la armonía de sus ritmos espaciales, sino por dar testimonio de autenticidad y por el hecho de ser depositario de identidad.

La representación de la ciudad es una de las constantes más permanentes en la historia del hombre. Es un hecho que el hombre ha representado lo urbano desde siempre y con múltiples finalidades: para alcanzar un conocimiento más profundo de sí mismo, como divertimento lúdico, como marco para integrar acontecimientos singulares, como escenario de tendencias de arquitectura o incluso como expresión de utopías. Teniendo en cuenta la secuencia de producción de representaciones establecida por Campos y Álvarez (2015), en la que se establecen cuatro etapas diferenciadas: la percepción de la realidad, la creación de la representación con una función y significado implícito, la difusión de la representación y la disposición por parte de otras personas de dicha información, podemos entender que todas ellas quedan de alguna manera almacenadas en nuestra memoria, de manera que de forma involuntaria "aquellas representaciones específicas sobre la ciudad son particularmente relevantes en la producción de nuestros imaginarios urbanos" (Campos y Álvarez, 2015, p.92) e incluso estas pueden estar enfocadas a inducirlo en una determinada dirección, como puede ser el caso de las políticas de desarrollo turístico. En este sentido, Vera (2015) analiza las estrategias turísticas y de valoración patrimonial fundamentadas en el imaginario urbano y cómo estas inciden en los procesos de configuración urbana. De igual manera establece que:

Existen vinculaciones entre el imaginario urbano vinculante, las políticas de urbanización y las de desarrollo turístico. Desde las políticas públicas se construyen ideas de lo que la ciudad fue, es y quiere ser apelando a aspectos sensibles y emotivos que tienden a disminuir las impresiones negativas tanto de la ciudad como del turismo (Vera, 2013, p.153).

Frecuentemente la representación es el testimonio de una realidad que se busca divulgar, más o menos idealizada, pero que también puede ser más o menos aterradora, ya que "los imaginarios corresponden a elaboraciones simbólicas de lo que observamos o de lo que nos atemoriza o desearíamos que existiese" (Lindón, 2007b, p.90). En este sentido, los miedos íntimos y también los desasosiegos de ciertos periodos históricos han generado entendimientos aterradores de la realidad urbana, y "ese puente entre la realidad y la representación mental se ha plasmado en el arte, porque el arte es siempre símbolo" (Delgado, Fernández, Márquez y Ramírez, 2007, p.166). Es el caso, por ejemplo, de la obra de Ludwig Meidner, pintor expresionista reconocido por sus paisajes apocalípticos previos a la Gran Guerra (Figura 10).

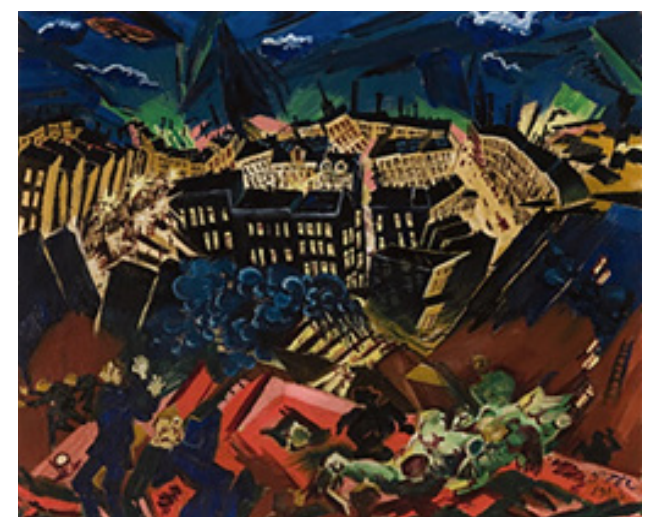

Figura 9: Ciudad incendiada. Ludwig Meidner (1884 1966)

Fuente: Saint Louis Art Museum. Recuperada el 28/03/2019 de:

https://www.slam.org/collection/objects/13506/ 
De tal modo, el análisis de la representación conceptualizada de lo urbano evidencia algo importante, y es que la ciudad resulta al mismo tiempo espléndida y aterradora.

\subsection{Validez metodológica de la iconografía para el entendimiento de la ciudad. La carto- grafía urbana.}

La representación de las ciudades, y también de territorio en el que están inmersas, siempre ha sido un aspecto fundamental de la definición cultural de los pueblos, y su imagen puede rastrearse desde su inicio en los principios de la relación entre el hombre y lo urbano. El propósito ha sido siempre mostrar cualquier cualidad de la ciudad estimada como destacable, aunque posiblemente no es hasta fines del s. XV y comienzos de s. XVI cuando por primera vez la relación entre la ciudad y su imagen queda establecida dentro de una convergencia de factores que determinan el especial valor de su expresión iconográfica. En este sentido, un ejemplo de compromiso con la visión paisajística y territorial de los núcleos urbanos y su entorno inmediato lo encontrarnos en las series de grabados realizados a lo largo del s. XV que, indudablemente, aportan más como fuente de información sobre lo urbano que los casi inexistentes documentos cartográficos hasta entonces disponibles.

El hecho de que el análisis de la iconografía urbana constituye un método eficaz y válido para desvelar e conocimiento de lo urbano y de lo territorial está hoy fuera de toda duda, porque la iconografía transmite una información que va más allá de su mero valor artístico, ofreciendo de hecho la posibilidad de conocer no solo la realidad física y formal que presenta sino también, sobrepasando su realismo, los valores, la cultura, y las inquietudes de la sociedad, que quedan atrapados en su representación. Por otra parte, las representaciones que pueden denominarse cartográficas han supuesto, desde siempre, una manera de entender lo territorial, y también frecuentemente han conllevado una enriquecedora visión sobre lo urbano. La percepción del territorio y su representación ha ofrecido siempre una visión de la relación hombre-territorio-ciudad a lo largo del tiempo, pasando siempre por muy variadas intenciones o pautas: utilitarias, instrumentales, divulgativas, militares, comerciales y aún otras muchas.

La tensión entre la representación de tipo paisajístico de la ciudad y la cartográfica, aun no nítidamente delimitadas, ha recorrido la historia hasta el afianzamiento científico de la cartografía. La ciudad ha sido representada como recurso informativo y también como recreación estética, imponiéndose en el primer caso la fundamentación cartográfica, frente a la paisajística del segundo, en la que predomina más la conceptualización analítica. Hay, en todo caso, que señalar que, aunque esa tensión entre la representación paisajística y la cartográfica sea una constante histórica, su expresión y significado han sido muy distintos en el tiempo, ya que prácticamente hasta comienzos del s. XVI, la representación de base cartográfica fue fundamentalmente territorial, y la paisajística predominantemente urbana, y no será hasta la aparición de las técnicas de representación renacentistas cuando propiamente surja y se desarrolle la cartografía urbana, ya plenamente definida en e pequeño plano de Ímola de Leonardo da Vinci de 1502 (Figura11).

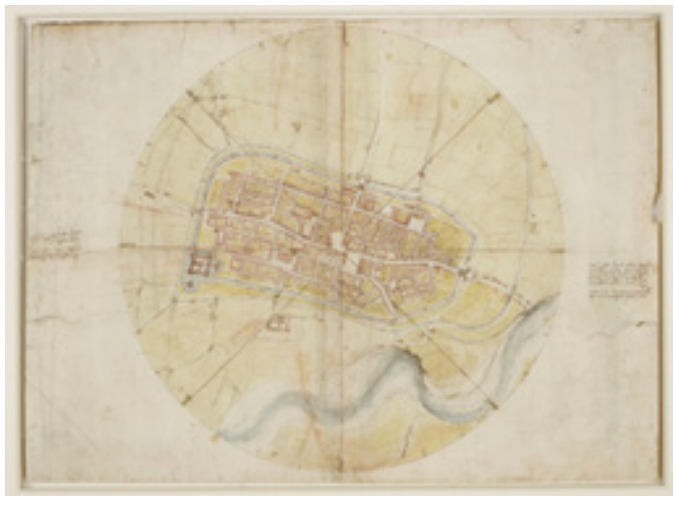

Figura 11: Ciudad de Ímola. Leonardo da Vinci, 1502 Royal Library del Castillo de Windsor.

Primer plano cartográfico urbano de la historia.

Fuente: Royal Collection Trust. Recuperada el 24/01/2019 de: https://www.rct.uk/collection/912284/anbspmap-ofimola

Rastrear sobre esta plasmación, en la que todo ello ha quedado inscrito como en un palimpsesto, es trabajo de investigador interesado en conocer la visión del mundo y de lo urbano.

\section{2 ¿La actual cartografía?}

Es un hecho que en la actualidad los mapas tradicionales casi han dejado de imprimirse. Hoy en día la cartografía se mueve en la era digital, generándose de manera que es fácilmente accesible y compilable por el usuario, que solo tal vez, en determinadas situaciones, decide imprimirla. En todo caso es posible que estas imágenes tomadas por satélite, que carecen de cartela, de título, de la barra de escala y de otros sellos distintivos de la cartografía tradicional, no sean en realidad mapas, y que los límites convencionales queden cada vez más desdibujados a medida que los mapas se asimilan a la mera compilación de datos. Con el desarrollo de la tecnología, los aspectos geográficos son cada vez más manipulables, escalables y flexibles, y se pueden visualizar en combinaciones innumerables y con apariencias muy diversas (Pelletier, 1999).

Al contrario que en el tradicional mapa de papel, donde la información es accesible visualmente, la mayor parte de los datos recolectados en la actualidad mediante sensores remotos no se pueden representar en un único marco, y así los datos de espectro múltiple que se recogen mediante el satélite carecen de sentido sin la interpretación y compilación adicional, siempre necesaria para tomar decisiones sobre qué se representa y cómo se representa. La esclarecedora imagen, tomada mediante el empleo de tecnología de espectro múltiple, que se muestra a continuación, derivada de datos obtenidos mediante satélite, y sometidos a técnicas de procesamiento y análisis, recoge el monte St. Helens después de una erupción volcánica en marzo de 2005. Al aportar los satélites imágenes terrestres con una gran frecuencia, y contando con una resolución espacial altísima, ya es posible representar visualmente todas las condiciones asociadas a los procesos terrestres. (Figura12) 


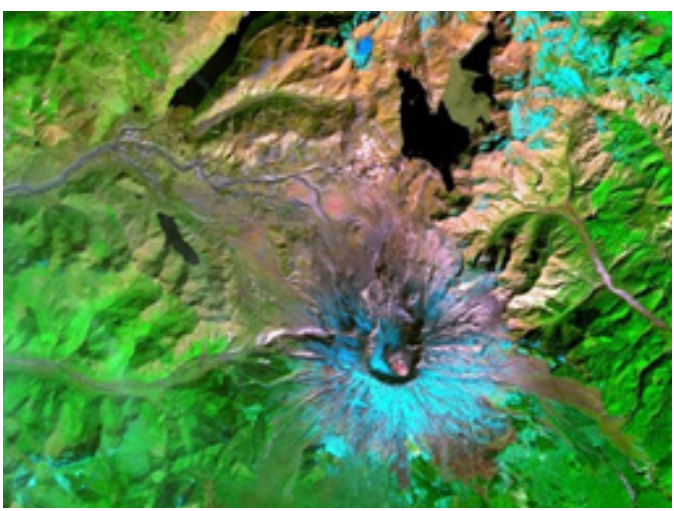

Figura 12: Monte St. Helens, Washington, 2005 Fuente: NASA. Recuperada el 24/01/2019 de: http:// concurso.cnice.mec.es/cnice2006/material121/80imag/ $\mathrm{xml} / 33 . \mathrm{htm}$

Tal vez esta desaparición de hecho de la cartografía no sea algo intrascendente, porque conducida inevitablemente a las nuevas tecnologías telemáticas y visuales, y bajo la apariencia de apertura a nuevos campos, queda realmente abocada al reduccionismo más limitador. Quizás sea así un aspecto más de nuestra condena a vivir alineados en un paisaje que ya no nos es representado, sino que solo se nos manifiesta virtualizado (Figura 13).

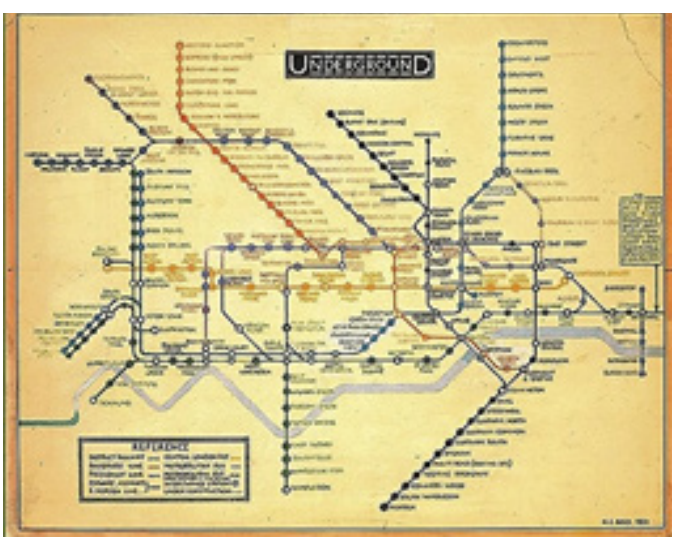

Figura 13: Plano-diagrama del metro de Londres. Harry Beck, 1931. Proceso intelectual de abstracción que, partiendo de la depuración de contenidos cartográficos y sacrificando la exactitud geográfica en favor de la claridad, alcanza la representación diagramática. Está considerado como un clásico del diseño gráfico, alcanzando el estatus de icono de la ciudad.

Fuente: Recuperada el 01/07/2019 de: https://www geografiainfinita.com/2016/04/de-como-el-autor-delmapa-de-metro-de-londres-fracaso-con-el-de-paris/

Hoy en día, las tecnologías de Información y comunicación nos ofrecen nuevas perspectivas para hacer una relectura de los imaginarios urbanos y compartir experiencias, generándose un proceso de rememorización que desplaza al imaginario tradicional del ciudadano (Rosas y García, 2018).

Las TICs ofrecen nuevas herramientas para la construcción del imaginario. El espacio virtual, definido como interfaz de puro tiempo y pura conectividad, es la interfaz que facilita recolectar el imaginario colectivo (Rosas y García, 2018, p.100).
La visión aérea de Google Earth permite la percepción global del territorio, posibilitando así su lectura. Cercas, surcos y trazos se manifiestan sobre la piel de la tierra, heridas indelebles que resultan especialmente significativas como huellas del hacer incrustado que se ofrece a la percepción. En todo caso, lo escrito sobre el territorio desvela al urbanista muchas cosas que pudieran carecer de sentido para sus autores, meros seguidores de los imperativos de la topografía o de una economía primaria. El territorio es un plano tan delgado y extenso que el escritor no puede comprobar el efecto de su inconsciente caligrafía sobre él, y así el que rotura, construye o arrebata, desconoce el efecto de su trabajo, incapaz de leer su propia caligrafía. Solo mucho más tarde y desde mucho más arriba será posible la lectura por el urbanista. Trazas, cercas de mampostería, geometrías... todo lo introducido sobre la superficie moldeable del suelo expresa algo, y los territorios, a veces despojados de su propio caos interno, adquieren otra categoría tras la introducción en ellos de un orden que priva a la naturaleza de su íntimo sentido, alejándola de los volúmenes lentamente esculpidos por el tiempo e introduciéndolos en un universo urbano-territorial a desvelar. En la ilustración, un paisaje rural que bien pudiera pertenecer al de una primitiva civilización, pero que es actual y corresponde realmente al interior de la turística isla de Mallorca (Figura 14).

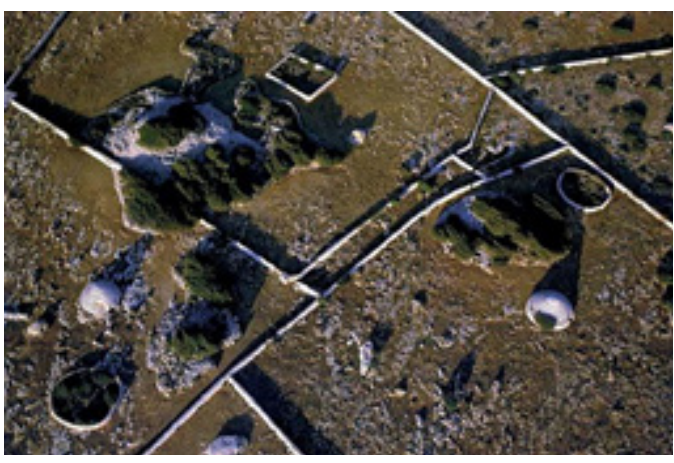

Figura 14: Paisaje rural de Mallorca

Fuente: Zoom sobre ortofoto de Google Earth.

\section{El imaginario de lo urbano como posible fundamento del orden reticular}

Como es sabido, a principios de los años 60 del siglo pasado se produjo una significativa aportación al entendimiento de lo urbano desde el análisis de la conceptualización de la imagen urbana. Se trató de una serie de trabajos de David Crane, Gyorgi Keppes, William Alonso y sobre todo Kevin Lynch y su conocida obra La imagen de la ciudad. Lynch centró su investigación no solo en los valores formales o arquitectónicos de lo urbano, sino también en los mecanismos y condiciones a través de los cuales se percibe la ciudad, resultando coherente la expresión "imagen de la ciudad" en relación con su entendimiento perceptivo y psicológicamente elaborado de lo urbano. 
La imagen no es el resultado de un hecho perceptivo vinculado directamente a lo visual, sino el resultado de una lectura intelectual y compleja de la realidad, siendo para Lynch la legibilidad el aspecto fundamental para la construcción de la imagen, y la orientación la clave para la representación mental de la imagen (Kanizsa, 1986). La imagen, como expresión de una manera compleja de comprender la forma, se fundamenta en la percepción visual, pero siempre dentro de una estructura de significados. Los elementos estructurantes, que Lynch define como sendas, bordes, nodos, etc..., son categorías empíricas útiles para una posible organización y, sobre ellas, se significa todo un sistema de lectura (Figura15).

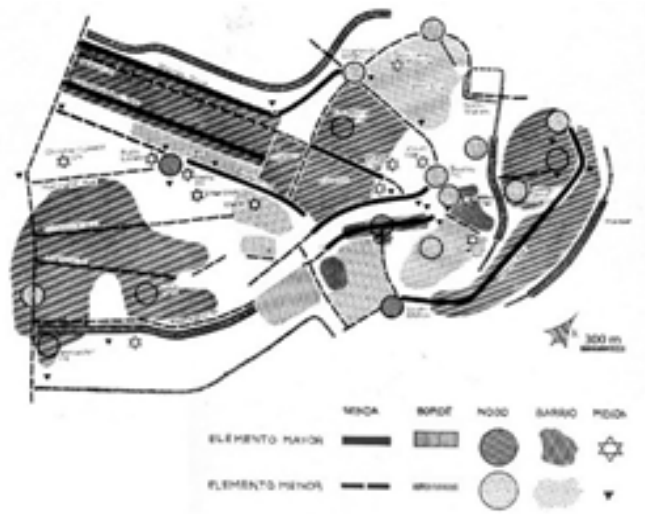

Figura 15: Trabajo sobre la ciudad de Boston. Kevin Lynch Planos-esquemas donde se puede apreciar: la forma visual sobre el territorio, su imagen obtenida mediante encuestación ciudadana, su imagen derivada del bosquejo de mapas $y$, finalmente, los elementos distintivos abstraídos del proceso.

Fuente: Lynch, K. (1984). La imagen de la ciudad. Barcelona, España: Gustavo Gili.

En el proceso de relación imagen-espacio no se pierde la referencia al mundo físico objetivo, pero esas categorías empíricas que estructuran la imagen se distancian de las meras geometrías justificadas en una perceptiva visual. En definitiva, es la abstracción del espacio urbano elevada al nivel de categoría intelectualizada la que conforma la imagen de la ciudad.

\subsection{La tendencialidad geométrica en la concep- tualización de lo urbano}

La ciudad, por su dimensión física y sobre todo por su inabarcable complejidad, desborda el campo visual del hombre y su capacidad sensorial, porque no puede ser percibida en su totalidad y, en última instancia, tampoco puede ser resultado de una única sensación básica, sino que requiere de actos perceptivos sucesivos y fragmentarios en los que fundamentar una imagen según el tipo de experiencias comprometidas en su lectura. El hombre, no obstante, siempre tiene una imagen de la ciudad que queda referida a lo que su conocimiento ha sido capaz de elaborar y a lo que su memoria ha retenido, siendo su capacidad perceptiva fundamental para la elaboración de esta imagen urbana, que es el resultado de un cúmulo de recuerdos que se superponen. A partir de este cúmulo de informaciones y experiencias es como se construye la "imagen de la ciudad", que tiene que superar una realidad desde su fragmentación y discontinuidad. En definitiva, y como proceso intelectual, la coherencia de la imagen tiene así que fundamentarse en la legibilidad y es preciso encontrar las leyes de coherencia que organizan las partes significativas de lo urbano hasta alcanzar un todo como resultado asumible.

Lynch elaboró así una teoría que puede considerarse en alguna medida gestáltica, en la que trata de obtener una estructura legible de la ciudad, sobre la base de que esa legibilidad de la forma urbana permite la definición de un orden en el interior del hombre, que trasciende como valor incluso más allá del de la propia ciudad. Es el orden, como fundamento de claridad en la imagen, el que proporciona al hombre una sensación de seguridad y de equilibrio interno, y es dentro de este orden donde puede mejorar y hacer más eficaces sus experiencias y su conocimiento. Todo el sistema de análisis de la forma urbana queda así de algún modo ligado a un cierto orden espacial y también a una perceptiva estética en su formalización, aun cuando, sin desligarse del fundamento visual en la percepción del espacio, la traslada a un cierto retardamiento vinculado a la memoria del observador, convertida ya en un espacio imaginado.

La búsqueda de legibilidad y de equilibrio interno contribuye al entendimiento abstracto de la fundamentación geométrica de lo urbano, que también está en la esencia de toda percepción. Frecuentemente la perfecta geometría que se aprecia, incluso con certeza, no coincide con la que existe realmente, y esto es un fenómeno conocido ya desde la antigüedad clásica. Ejemplo de ello es la ciudad de Briviesca, la "Virovesca" romana. Con independencia de su extraordinaria significación urbana, la referencio aquí, acompañada de su representación por Coello, como evidencia de la ceguera existente ante ciertas imperfecciones formales, ya que su percepción es de perfecta regularidad sobre la mera imagen retiniana, como queda evidenciado en su errónea cartografía (Figura 16 a y b)

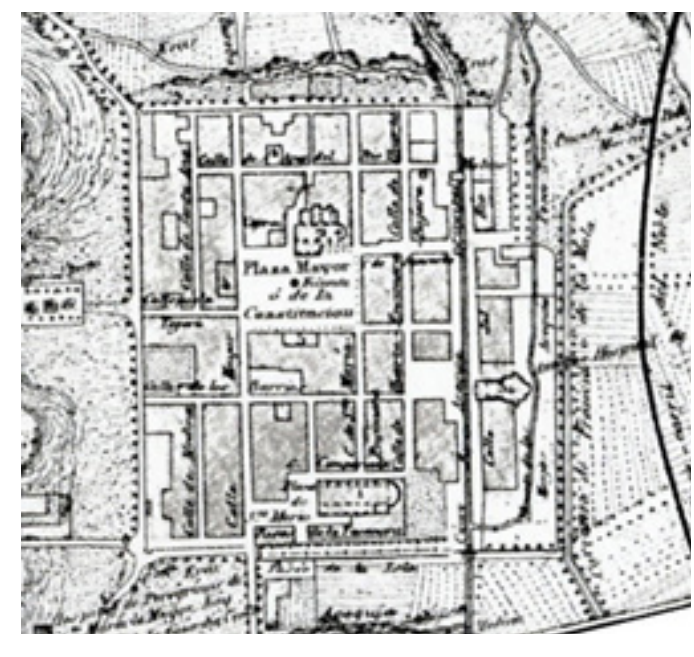

Figura 16 a: Mapa de Briviesca (1868), por Francisco Coello.

Fuente: Goytia, M.D. (2011). Gestación de la ciudad en la gesta de España. Desde su origen a la maduración Plenomedieval (Tesis Doctoral). Universidad de Sevilla (ETSA), Sevilla, España. 


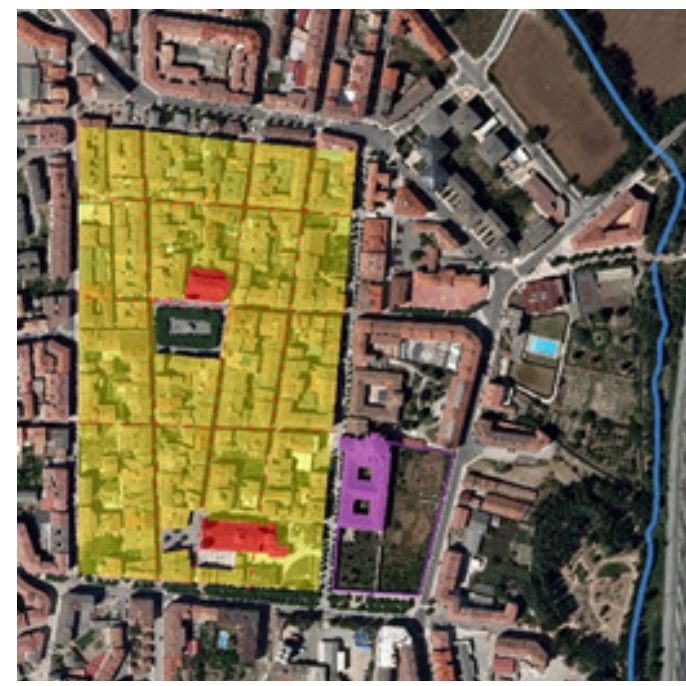

Figura 16 b: Briviesca en Google Earth.

Fuente: Goytia, M.D. (2011). Gestación de la ciudad en la gesta de España. Desde su origen a la maduración Plenomedieval (Tesis Doctoral). Universidad de Sevilla (ETSA), Sevilla, España.

\subsection{La retícula como inmediata respuesta per- ceptiva ante las nuevas fundaciones urbanas}

Es en la actitud perceptiva del hombre sobre la que se sustenta su interés por encontrar un orden para lo urbano, fundamentado a su vez en la lógica de la regularidad. De hecho, y según se ha analizado, la percepción como experiencia vital trata siempre de desvelar las claves ordenadoras de lo urbano, y de aquí que, de forma históricamente recurrente y quizás incluso más allá de razones meramente funcionales, el proyecto fundacional de casi toda nueva ciudad se ha sustentado casi siempre sobre estructuras morfológicas de fácil lectura perceptiva, y también sobre esquemas organizativos modulares o repetitivos en la organización del espacio urbano.

La presencia de retículas como orden subyacente en la organización primaria del espacio urbano ha sido así, desde las civilizaciones primitivas, un recurso eficaz como soporte para la lectura de lo urbano, y la historia de la fundación de nuevas ciudades ofrece incontables ejemplos, en las más variadas escalas y ante muy diversos supuestos y, desde Zernaki-Tepe en Anatolia, y Khorsabad y Babilonia en Mesopotamia, y aun posiblemente antes, la retícula ha sido el argumento más primario al que el hombre civilizado ha recurrido casi de forma mecánica a tener que afrontan proyectualmente el reto organizativo del espacio urbano.

Curiosamente, la fundación de nuevas ciudades debiera haber sido el campo ideal para plantear propuestas morfológicas y espaciales de órdenes compositivas novedosas, pero la historia desvela que no ha sido así, y que la presencia ordenadora de la retícula casi siempre ha impuesto su presencia, lo que sin duda también está justificado en motivaciones funcionales y de vertebración urbano-territorial, significando las regulares trazas, sobre su carácter formal, una pura abstracción con su claridad organizadora. En ocasiones, el exceso de celo geométrico se ha entendido como pobreza formal y pérdida de libertad expresiva; no obstante, sobre tramas rígidamente geométricas, se han sabido construir los más expresivos paisajes urbanos. Ejemplo de ello es la ciudad española en América, los ensanches decimonónicos o las trazas escenográficas del París del barroco (Arias, 2002) (Figura 17).

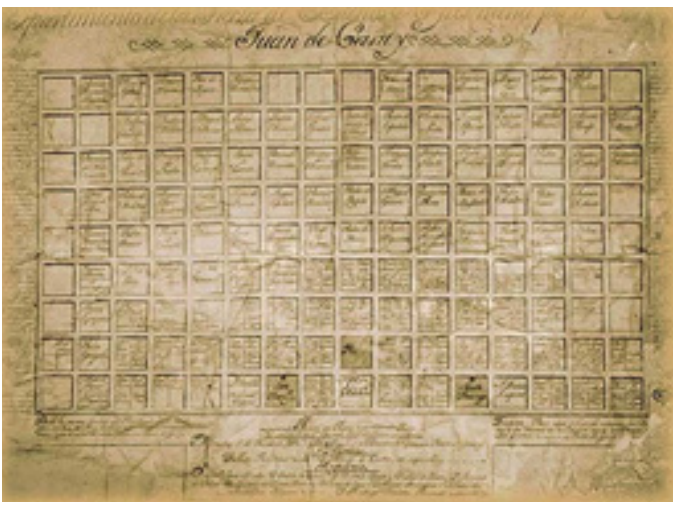

Figura 17: Plano de fundación de Buenos Aires 1583

Fuente: Geografía infinita. Recuperada el 03/07/2019 de: https://www.geografiainfinita.com/wp-content/ uploads/2018/06/plano_fundacion_1580.jpg

En definitiva, la reticulación morfológica y espacial se constituye en argumento ordenador de lo urbano, y la traza reticular significa así, y quizás por encima de fundamentaciones más inmediatas, el principal soporte de lectura de lo urbano, siendo esta organización la que posibilita la coherencia como seña de identidad.

\section{Conclusiones}

Todo aquel que representa gráficamente el espacio, sea el cosmos, el territorio, lo urbano, o lo arquitectónico, conoce el objeto al que debe servir su representación e incluso, más allá de ello, es guiado inconscientemente por los valores e ideas del tiempo, de la cultura, y del mundo en que vive, aunque esté en conflicto con sus propios valores o esté en desacuerdo con él. Así, puede constatarse que toda representación siempre tiene presente una dimensión significativa o simbólica, que se establece socialmente incluso al margen de la intencionalidad consciente del que la lleva a cabo, y que es susceptible de ser reconocida y analizada.

A través de un proceso intelectual, el hombre ya civilizado construye su imagen de la ciudad, proceso en el que busca una estructura legible, tendencialmente ligada al espacio regular e incluso geométrico, constituyendo esta imagen la fundamentación básica para la plasmación del imaginario colectivo de lo urbano. El imaginario urbano así conceptualizado, por su abstracción y también por su valor simbólico, tiene vocación de universalidad y, consecuentemente, constituye también un potencial proyectual relevante, e incluso también una categoría inductiva para la proyectación de lo urbano, especialmente para la fundación de toda nueva ciudad, donde se intenta la de- 
finición previa, formal y regular del orden urbano inscrito en el orden cósmico.

Históricamente se constata que esa lógica de la regularidad, perceptivamente buscada, se ha plasmado de forma recurrente desde las civilizaciones primitivas, siendo particularmente eficaz en los procesos colonizadores, que por supuesto son urbanos pero que también son territoriales. La necesidad de equilibrio interno en un sistema legible que le permita al hombre sentirse seguro en una realidad cósmica, territorial y urbana entendida y aprehendida explica la aparición y utilización del orden reticular en lo urbano.

Lo que no hay que olvidar, es que esta realidad, casi inherente al hombre e inscribible en su necesidad de entender el mundo para entenderse a sí mismo, conduce a la mera disposición y utilización mecánica del orden reticular, carente así de otras cualidades y significados, reducido solo a soporte o traza espacial satisfaciente de los aspectos que he referenciado. En este sentido, parece quedar cerrada la tan habitual referencia a integrar en la misma reflexión todas las recurrencias al orden reticular producidas a lo largo de la historia, que la mayor parte de las veces nada tienen que ver entre sí, salvo la utilización de una traza geométrica, lo que confunde más que aclara si solo se referencia el análisis a este estrecho marco.

La traza regular ciertamente existe desde las civilizaciones primitivas, pero allí y en su origen solo procede y concluye en esta necesidad primaria del hombre civilizado, mientras que en otros contextos culturales, obviamente mucho más evolucionados, los significados del orden reticular serán múltiples y complejos, tanto como la ciudad que sobre ellos se sustenta, y eso se aprecia ya en la ciudad española plenomedieval, y quedará después plasmado en la ciudad española en América, decantándose a través de un dilatadísimo proceso cultural y desarrollada en sus claves y fundamentos esencialmente durante la Reconquista.

También en lo territorial, y no solo en lo urbano, el orden geométrico se ha impuesto frecuentemente, si bien en el territorio son más bien conveniencias funcionales las que prevalecen sobre las de claridad perceptiva. Tanto en la experiencia colonizadora clásica romana, como en la española en América, inmensamente superior en extensión y significado, la ordenación urbana y territorial comportan una lógica estructurante, si bien en la romana esta última induce aquella, mientras en América es la ciudad la que extiende su código ordenador sobre el territorio (Figura 18).

En la actualidad, inmersos en la era digital, la gran cantidad de datos generados y capas obtenidas a partir de aquellos, sustituyen lo real por lo virtual, desvelándonos, a través del uso de las nuevas tecnologías, nuevas leyes espaciales que anteriormente permanecían ocultas e ignoradas, escapaban a nuestra propia percepción y por lo tanto no formaban parte del imaginario urbano.

Las nuevas herramientas digitales, y las nuevas metodologías que nos permiten captar la dimensión subjetiva del espacio urbano, se pueden configurar como nuevas estrategias a partir de las cuales mejorar la percepción de la ciudad y el territorio, compartir imaginarios urbanos, y resolver los problemas que genera la ciudad fragmentada en la configuración del espacio público.

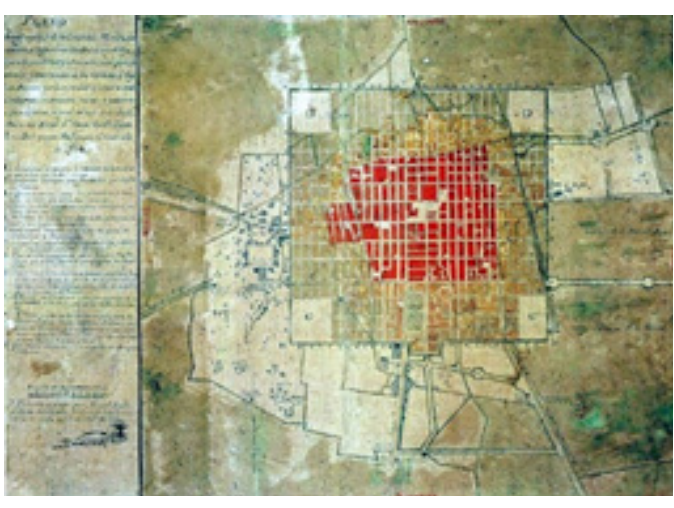

Figura 18: Plano urbano-territorial de México

El plano orientado al este, fue dibujado por Manuel Ignacio de Jesús del Águila para el Virrey D. Juan Vicente Güemes Pacheco de Padilla, quien entre el 1789 y 1794 llevó a cabo grandes obras que transformaron la soberbia capital de Nueva España.

Fuente: World Digital Library. Recuperado el 24/01/2019 de: https://www.wdl.org/es/item/190/view/1/1/

Cómo citar este artículo/How to cite this article: Goytia-Goyenechea, L. y Martínez-Roldán, N. (2020). Conceptualización de la ciudad y su territorio. Tendencia geométrica del imaginario urbano. Estoa. Revista de la Facultad de Arquitectura y Urbanismo de la Universidad de Cuenca, 9(17), 79-92. doi: 10.18537/est. v009.n017.a07 


\section{Referencias bibliográficas}

Arnheim, R. (1997). Arte y percepción visual. Madrid, España: Alianza Editorial.

Arias, P. (2003). Periferias y Nueva Ciudad. El problema de paisaje en los procesos de dispersión urbana. Sevilla, España: Departamento de Urbanística y Ordenación del Territorio de la Universidad de Sevilla.

Arias, P. (2002). El arte como compromiso crítico frente a la Ciudad. Sevilla, España: Departamento de Urbanística y Ordenación del Territorio de la Universidad de Sevilla.

Augé, M. (2000). Los no lugares, espacios del anonimato. Barcelona, España: Gedisa S.A.

Avendaño, J.A. (2017). Representaciones socio - espaciales (toporrepresentaciones) de Bogotá: perspectivas de la (in) seguridad. Sociedad y economía, (33), 55-75.

Campos, L. y Álvarez, R. (2015). La mecánica de producción de los imaginarios urbanos: dos ejemplos de investigación para el caso de Santiago de Chile. Revista de Urbanismo (33), 87-103. Recuperado de http://repositorio.uchile.cl/ bitstream/handle/2250/137035/La-mecanica-de-produccion-de-los-imaginarios-\%20urbanos-dos-ejemplos-de-investigacion-para-el-caso-de-Santiago-de-Chile.pdf;sequen$\mathrm{ce}=1$

Chías, P. (2018). La representación de la ciudad, del territorio y del paisaje en la revista EGA: Mapas, planos y dibujos. EGA Expresión Gráfica Arquitectónica, 23 (34), 106-121.

Delgado, A.H., Fernández, F.J., Márquez, M.L. y Ramírez, V. (2007). Análisis de la imagen urbana de la ciudad de Granada. Hitos y nodos a través de su historia. EGA Expresión Gráfica Arquitectónica, (12), 166-175.

Di Siena, D. (2010). Espacios sensibles, Hibridación físico-digital para la revitalización de los espacios públicos (Trabajo de maestría). Escuela Técnica Superior de Arquitectura de Madrid (UPM), Madrid, España.

Folch, R. y Bru, J. (2017). Ambiente, territorio y paisaje. Valores y valoraciones. Madrid, España: Barcino S.A

García, E. y García, J. L. (1972). España dibujada. Madrid España: Servicio central de publicaciones del Ministerio de la vivienda.

Goytia, M. D. (2011). Gestación de la ciudad en la gesta de España. Desde su origen a la maduración Plenomedieval (Tesis Doctoral). Universidad de Sevilla (ETSA), Sevilla, España.

Hiernaux-Nicolás, D. (2002). Turismo e imaginarios. Cuaderno de ciencias sociales (123), 7-35. Recuperado de http:// biblioteca.clacso.edu.ar/ar/libros/costar/cua123.pdf

Kanizsa, G. (1986). Gramática de la Visión: percepción y pensamiento. Barcelona, España: Paidós Ibérica.

Leonardo, G. (2004). La definición del concepto de percepción en psicología con base en la teoría Gestalt. Revista de Estudios Sociales, (18), 89-96. Recuperado de https://www. redalyc.org/articulo.oa?id=81501809.
Lindón, A. (2007a). La ciudad y la ida urbana a través de los imaginarios urbanos. EURE (Santiago), 33(99), 7-16. Recuperado de https://www.researchgate.net/publication/250371450_La_ciudad_y_la_ida_urbana_a_traves de_los_imaginarios_urbanos

Lindón, A. (2007b). Diálogo con Néstor García Canclini. ¿Qué son los imaginarios y cómo actúan en la ciudad?. EURE (Santiago), 33(99), 89-99. Recuperado de https://www.redalyc. org/articulo.oa?id=19609908.

Lynch, K. (1984). La imagen de la ciudad. Barcelona, España: Gustavo Gili.

Pelletier, M. (1998). Couleurs de la Terre: des Mappemondes medievales aux images satellitales. París, Francia: Bibliothèque nationale de France.

Rosa, C. y García, A. (2018). El impacto de las TICs en e imaginario urbano. Nuevas herramientas digitales en la dialéctica territorio líquido vs ciudad tradicional. Imagonautas, revista interdisciplinaria sobre imaginarios sociales, (11), 82 106. Recuperado de http://imagonautas.webs.uvigo.gal/index.php/imagonautas/article/view/97.

Sáinz, L.I. y González, J. (2015). El territorio y sus representaciones. Lecturas filosóficas, geográficas y urbanísticas. México: Universidad Autónoma Metropolitana.

Santaella, J.M. (2019). Juan Manuel Santaella, artista plástico. Recuperado de https://juanmanuelsantaella.com/

Stulberg, S. (2010-2019). Scott Stulberg Photography. Neon Sky Creative Media. Recuperado de http://asa100.com/

Terán, F. (2002). Medio siglo de pensamiento sobre la ciudad. Madrid, España: Real Academia de Bellas Artes de San Fernando.

Uribe, I. (2005). El problema de la idea y su representación a partir de Ernst Gombrich. AISTHESIS (38), 73-91. Recuperado de http://revistaaisthesis.uc.cl/index.php/rait/article/ view/499.

Vera, P. (2013). Imaginarios urbanos y procesos de urbanización en las nuevas ciudades turísticas. El caso de la ciudad de Rosario, Argentina. Bitácora 22, (1), 153-162. Recuperado de https://revistas.unal.edu.co/index.php/bitacora/article/viewFile/34607/pdf_477

Vera, P. (2015). Estrategias patrimoniales y turísticas: su incidencia en la configuración urbana. El caso Rosario, Argentina. Territorios (33), 83-102. Recuperado de https:// revistas.urosario.edu.co/index.php/territorios/article/ view/3352/3088

Zenteno, E. (2018). La percepción del espacio urbano. E aporte de los mapas perceptivos al análisis del barrio ZEN de Palermo (Italia). Revista INVI, 33 (93), 99-122. Recuperado de http://revistainvi.uchile.cl/index.php/INVI/article/ view/1236 